\title{
Impact of Ownership Structure on Firm Performance in the MENA Region: An Empirical Study
}

\author{
Neveen Ahmed ${ }^{1}$ \& Ola Abdel Hadi ${ }^{1}$ \\ ${ }^{1}$ The American University in Cairo, Egypt \\ Correspondence: Neveen Ahmed, The American University in Cairo, Management Department, AUC Avenue. P.O \\ Box 74, New Cairo 11835, Cairo, Egypt. E-mail: nahmed@aucegypt.edu
}

Received: July 1, 2017

Accepted: August 1, 2017

Online Published: August 8, 2017

doi:10.5430/afr.v6n3p105

URL: https://doi.org/10.5430/afr.v6n3p105

\begin{abstract}
This paper investigates the impact of ownership structures on firm financial performance in the MENA region. The sample covers nine MENA countries (Egypt, Bahrain, Qatar, Kuwait, Tunisia, UAE, Morocco, Oman and Jordan) for the year 2014. We examine the impact of ownership structures on firm performance. Performance is proxied by Tobin-Q, ROE and ROA, while ownership structure is proxied using insider ownership, governmental, and blockholders. We control for risk, size, country effect and industry type. Our results suggest that blockholders, insider ownership and governmental ownership play a crucial role in firm performance measured by Tobin-Q, ROE and ROA respectively. Our results suggest that insider ownership negatively effects firm's return on equity, while blockholder ownership has a positive impact on a firm's Tobin-Q. Finally we find that governmental ownership plays a positive role on a firm's return on assets in the MENA region.
\end{abstract}

\section{JEL Classification: G0, G30}

Keywords: Ownership structure, MENA region, Firm performance

\section{Introduction}

A firm's ownership structure is composed of investors, financial institutions, mutual funds, international firms, blockholders, family members and managers. The impact of ownership structure on firm performance is derived from the agency theory. The separation of management from control creates a "principal-agent problem" in which managers (agent) might make decisions that are not in the best interest of the owners (principal). Managers may use private information for their own benefit and act against shareholders' interests and views. This managerial opportunism, in which managers seek self-interest through deceit can prevent maximization of shareholder wealth.

In developing countries, corporate governance impacts public policy objectives. Good corporate governance reduces emerging market vulnerability to financial crises, strengthens property rights, reduces transaction costs and the cost of capital, and leads to capital market development. Weak corporate governance frameworks reduce investor confidence, and can discourage outside investment. Moreover, since pension funds are invested in equity markets, good corporate governance is vital for preserving retirement savings. Over the past decade, the importance of strong corporate governance has been emphasized by a growing body of academic research. Studies show that good corporate governance practices have led to significant increases in the economic value of firms, higher productivity, and lower risk of country-wide systemic financial failures. Nevertheless, there is limited empirical research done on the MENA region.

In this paper we study the relationship between ownership structures and firm performance. Focusing on MENA region contributes to existing literature of the impact of ownership characteristics on firm performance, which could give insight to policy maker and investors in the MENA region. A vast strand of literature has examined the relationship between ownership structures - such as family ownership, blockholder ownership (we define Block-holders as the sum of the 10 largest investors owning shares in the company), ownership by management - and a market based indicator for performance, which is measured mostly with Tobin's Q and/or financial performance. However, most of these studies cover Europe and the USA (Demsetz\&Lehn, 1985; Demsetz\&Villalonga, 2001; Shleifer, Morck\&Vishny, 1988; Andres, 2008; Anderson \&Reeb,2003). To our knowledge, only a few papers have studied the impact of ownership structure and firm performance in the MENA region. We examine data on firms from nine countries: Egypt, Bahrain, Qatar, Kuwait, Tunisia, Dubai, UAE, Morocco, Oman and Jordan. We then 
study the relation between ownership structure and firm performance proxied by Tobin's Q, ROA and ROE.

The relation between ownership structure and firm performance is related to the "agency problem." Agency problems can affect a firm's performance, and may be attributed to various internal and external mechanisms. Internal mechanisms include ownership concentration, the board of directors, and executive compensation. Ownership concentration can be proxied using different variables. For example, large blockholders, who have a strong incentive to closely monitor a firm, may acquire seats on the board, which enhances their ability to monitor effectively. The increasing influence of institutional owners like stock mutual funds and pension funds, as they have the proxy voting power and incentive to discipline ineffective top-level managers and can affect a firm's choice of strategies. In addition, shareholders can assemble to discuss a corporation's direction; if a consensus exists they can vote as a block to elect their candidates to the board.

Another internal mechanism is the role board of directors. They have the power to direct the affairs of the organization, punish and reward managers, and protect owners from managerial opportunism. The effectiveness of a board of directors could be improved through diversification in the background of board members, stronger internal management and accounting control systems, and change in compensation of directors. Executive compensation includes salary, bonuses, long term performance incentives, stock awards, stock options or superannuation. There are several stumbling blocks that limit the effectiveness of executive compensation, such as unintended consequences of stock options, balance sheets not showing the executive wealth, or options not being expensed at the time they were awarded. The factors that complicate executive compensation may be the complex strategic decisions taken by top-level managers that affect the firm in the long run and other variables affecting the performance over time.

There is no consensus in the literature of the impact of various internal mechanisms on a firm's performance.For example, Elyasiani and Jia (2010) and Barzegar and Babu (2008) found a positive relationship between profitability and institutional ownership. While Dinga's (2011), Pham et al.(2011) and Faccio and Lasfer (2000) found a negative relationship. There is also disagreement in the literature on the impact of insider ownership on profitability. Seifert, Gonenc and Wright (2005), Morck, Shleifer, and Vishny (1988) and Yammeesri (2003)found a positive relationship between insider ownership and firm performance. However, Demsetz (1983) argues that insider ownership is internally derived so it has no credible impact on firm value.Yammeesri (2003) foundthat government, financial institution, and bank shareholders ownership had no impact on profitability. On the other hand, Nickel (1997), Thomsen and Pedersen (1997), Andres (2008), and Perotti (1995) assert that state ownership leads to bureaucracy and inefficiency, which negatively impacts performance. Ongore(2011) supports Nickel's (1997) theory of the negative effect of government ownership on a firm's performance.

This paper empirically investigates the relation between ownership structure and firm performance. We cover nine countries in the MENA region for year 2014.The paper is organized as follows: section two presents literature review and hypothesis development; section three is a description of the data; section four discusses the model and methodology; section five discusses results; and section six provides a conclusion.

\section{Literature Review and Hypothesis Development}

This section presents a literature review of the relationship between ownership structures and firm performance. Ownership structure is represented by insider ownership, government agency, and institutional investors.

\subsection{Insider Ownership}

Ngui, Voon and Lim (2008)argue that there is a positive effect of internal management on firm value.They argue that this favorable effect is due to the valuable information possessed by insiders compared to that possessed by outsiders. This leads to insider dominance and stronger performance, since ownership and management are aligned in interest and have a long-term investment perspective. Seifert, Gonenc and Wright (2005)attribute the positive relation between insider ownership and performance to the alignment of interest between stockholders being a family member and in the management, leading to maximization of shareholder wealth.

Morck, Shleifer, and Vishny (1988) surveyed371 Fortune 500 firms in 1980. The researchers found that in the 0 to 5 percent insider ownership range there is a positive relationship. With ownership above 25 percent there is a weak effect, but the range between 5 to 25 percent negatively affects Tobin's Q performance. A positive relation occurs when using the convergence of interest hypothesis. Low agency costs lead the equity shares of insiders to increase with an increase in market valuation. A negative relation occurs based on the entrenchment hypothesis where the insider ownership, after reaching a certain level, spirals downward due to the conflict between management and dispersed shareholders. This decline is caused by the management's gain of too much power and the usage of the firm for personal interest, which consequently leads to a bellshape relation between inside ownership and firm value. 
Demsetz (1983) argues that insider ownership is internally derived so it has no credible impact on firm value; an argument that is supported byDemstez and Lehn (1985) who contend thatfirm size, volatility, ROA, and industry affiliation are considered to be significant explanatory variables for the ownership structure of US firms. Loderer and Martin (1997), and Himmelberg, Hubbard, and Palia (1999)contend that the market's competitive environment shapes a firm's choices for the maximized ownership structure, which lead to the conclusion that insider ownership does not have an effect on performance. Yammeesri (2003)evaluated a sample of the four years before Thailand's 1997 financial crisis and found a positive relationship between managerial ownership and firm performance. Yet after the crisis, from 1998 to 2000,there was an insignificant relationship, which was likely due to the managerial ownership diverting resources for their personal use and benefits, or the absence of strong legal protection of minority shareholders, as well as other external factors such as takeovers.

Krivogorsky(2006)founda weak relationship between managerial ownership and profitability in European companies. She justifies this as a result of economic incentives provided through active managerial monitoring of the firm's environment. However, managerial ownership can encourage risk taking, which could damage the firm's profitability instead of improving it. Eelderink (2014) uncovered no significant relation between managerial ownership and performance and his results support the findings of Krivogorsky (2006).

We build our first hypothesis:

$H_{A 1:}$ There is a positive significant relationship between insider ownership and firm performance.

\subsection{Governmental Ownership}

Governmental ownership is characterized by the ease of accessing funds, power and resources. However, they do differ in objective. Institutional investors only aim to make a profit, but the government, in addition to profit, may want to reduce unemployment, increase tax collection, or stabilize the economy. Borisova et al. (2012) claim that governmental ownership has a positive effect on firm performance because it can quickly demand information through regulations that reduce the information asymmetry. Jiang, Laurenceson, and Tang's (2008)study on listed companies inthe2004 Shanghai Stock Exchange (SSE) found a positive impact of government ownership on ROE. Similar results were found byNg, Yuce and Chen (2009), who attributed this positive relation to the benefit of government support and protection from industry subsidiaries.

Yammeesri (2003) found that the profitability ratio was not significantly affected by government, financial institution, and bank shareholders. Nickel (1997) asserts that state ownership leads to bureaucracy and inefficiency, which negatively impacts performance. Ongore(2011) supports Nickel's (1997) theory of the negative effect and adds that other than the bureaucracy in Kenya, there is also tribalism, poor human resources policies, and disrespect for the law. Likewise, Andres (2008) and Perotti (1995) mention that government blockholders have significant negative regression coefficients with the accounting dependent measures. Thomsen and Pedersen (1997) indicate that the negative association between firm performance and government ownership is a result of government playing a dual role as regulator and owner. Conflict develops when a government-controlled firm pursues trade-off strategies between shareholder value as owners and other objectives as regulators.

Many scholars have claimed that government-owned firms are political enterprises with citizens as the shareholders, but these citizens have no direct claim to the residual income of those firms. The citizens thus abandon their ownership rights to abureaucracy that does not have clear incentives to improve corporateperformance (De Alessi, 1980, 1982; Vickers \&Yarrow, 1988; Shapiro \&Willig, 1990; Shleifer \&Vishny, 1997).

We build our second hypothesis:

$H_{B 1}$ : There is a positive relationship between governmental ownership and firm performance.

\subsection{Blockholders Ownership}

Various studies have noted positive associations between firm's performance and blockholder ownership. Aggarwal et al. (2011), who investigated institutional ownership's effect on firm value in non-US companies, found that there was a positive link between both variables. Elyasiani and Jia (2010) and Barzegar and Babu (2008) asserta positive relationship between profitability and institutional ownership. Barzegar and Babu (2008) also declare a positive relationship between the ROA and institutional ownership. Institutional investors have the ability to absorb and process information, which decreases the information asymmetry. As a result, these investors are able to provide effective monitoring compared to less prudent and less informed investors (Davis and Steil, 2001). Chung and Zhang (2011) claim that institutional owners have a lot of funds to invest and exhibit strong fiduciary responsibilities, so they are eager to see their firms perform well. Also, they want to reduce free riders so they closely monitor since the 
possibility of exit could be expensive.

Empirical studies have examined the relationship between blockholder ownership and its effects on firm performance. Berle and Means (1932) and Shleifer and Vishny (1986) agree that the aim of ownership concentration aided in avoiding free riding problems and decreased the difficulty in monitoring managers. Outsiders are motivated to become large blockholders $\mathrm{s}$ because of the concentrated control and the private benefits. The blockholders achieve concentrated control when they hold a large interest in the company and heavy voting rights. As a result, they become involved with the operating decisions of the firm. As for the private benefits that can be achieved when blockholders use their power over management (Connellyet al., 2010).

The findings of Cho and Kim (2007), in which they sample 600 Korean firms, suggest that there is both a positive and negative relationship, but it depends on the level of concentration of the blockholders. Their research indicates that the firm benefits from a certain small increase in ownership due to the alignment of management and ownership interest; yet when the ownership profoundly increases it eventually negatively affects the firm because prevailing shareholders become invulnerable to the external market discipline. Hill and Snell (1988) proposethat by using profitability as a tool for performance measurement, that ownership concentration had a positive impact. They explain this by assuming that ownership concentration encourages innovative strategies that help maximize value and discourage diversification. McConnell and Servaes (1990) do not find supporting evidence to prove there is a direct link between large shareholders and firm value, even though their results point to a possibility of specific concentration of influence in insider ownership. Herfindahl index was used as a tool for ownership concentration and firm return was used as a measurement for firm performance. Mudambi and Nicosia (1998) found a negative relation between firm performance and ownership concentration, although there was a positive effect of increased control entrusted to the large shareholding groups on performance.

Tribo, Berrone, and Surroca (2007) believe that the existence of a large number of blockholders decreases the control of monitoring managers because responsibilities are diluted among a number of dominant large blockholders, which in return weakens firm performance. Lins (2002) also investigated a sample of 1433 firms from 18 emerging markets to discover the relationship between non-management blockholders and firm value. His concluding results were positive concerning the company's profitability measurement of Tobin's Q. His investigation proved that large non-management blockholders can lessen the valuation discounts accompanying the expected agency problems.

We build our third hypothesis:

$H_{C I}$ : There is a positive relationship between Block-ownership ownership and firm performance.

\subsection{Control Variables}

We control for the effect ofrisk on performance using firm's beta. Beta is used to examine firm performance in several studies. Anderson et al. (1998) also control for risk, but by using standard deviation of weekly returns. Maury (2006) uses growth in net sales as a proxy for capturing growth opportunities by averaging growth over a three year period. He found a positive relationship between sales growth and ROA. Aggarwal et al., (2011) measured growth as two year annual sales growth in U.S. dollars and reached the same results as Maury (2006).

We control for the effect of leverage on firm's performance, following Maury (2006), and Wei \& Varela (2003). An, Jin and Simon (2006), argue that high values of leverage should be related to lower fractions of shares owned by the larger shareholders, so the ownership structure of the firm will become more diffused (Kapopoulos and Lazaretou, 2007). Barzegar and Babu (2008) show that companies with higher debt to asset ratio (leverage) have lower returns compared to companies with less debt. This implies an inverse relationship between debt to asset ratio (leverage) and firm performance. Finally, we use a dummy variable for industry type following Anderson and Reeb (2004), who suggest that it is important to control for industry affiliation since family firms appeared to be dominant in several sectors.

\section{Data}

We use Eikon for each company to capture its ownership structure. The uniqueness of our data set emerges from the fact that ownership data is not available for each market; rather data is collected company by company for each country in our sample. Our sample comprises panel data of nine countries; a total of 252 MENA firms. Our sample includes Egypt, Bahrain, Qatar, Kuwait, Tunisia, Dubai, UAE, Morocco, Oman and Jordan. We use the most active index in each country retrieved from DataStream. We use cross-sectional data for 2014. Banks were excluded due to their complex nature and ownership structures compared to traditional firms. The dependent variables and control variables were also derived from the DataStream database. 
We proxy firms' ownership structure using three variables: insider ownership, government agency, and institutional investors. In_OS is insider ownership, defined as the percentage of shares held by board members and those who hold a managerial position within a firm and have an active role in running the firm. Block-OS is the sum of the ten largest investors owning shares in the company. They normally have easy access to a large amount of capital for investment. Gov_OS is government agency ownership, which is investment arms run on behalf of a governmental agency. Examples include the City of Tampa, Abu Dhabi Investment Authority, Federal Reserve Board of Governors, and Ohio Bureau of Worker's Compensation.

We proxy firm performance by the following variables: return on equity (ROE) and return on assets (ROA) and Tobin-Q. ROA is defined as((Trailing 12 Months Net Profit + (Trailing 12 Months Interest Expense on Debt* (1-Tax Rate / 100)))) / Average of Last Year's and Current Year's Total Assets * 100. ROEis defined as (Net Income - Bottom Line - Preferred Dividend Requirement) / Average of Last Year's and Current Year's Common Equity * 100.Tobin-q: is the market value/bookvalue.

We use the following control variables: firm size, industry type, sales growth rate, leverage, and risk. Firm size is measured as the natural logarithm of total assets. We use country dummies and Fama-French industry dummies to control for country and industry effects. In our sample, industrial firms is the most common type of industry is industrial type. It contributes $70.51 \%$ of the selected sample. We define industry type as follows: 01 Industrial, 02 Utility, 03 Transportation, 04 Insurance, 05 Other Financial. We use firms' Beta to proxy risk and measure leverage as total debt divided by total assets. Total debt represents all interest bearing and capitalized lease obligations. It is the sum of long and short term debt. Table 1 presents summary statistics of the variables we use in our model.

Table 1. Descriptive statistics

\begin{tabular}{llllllllllll}
\hline & INSID_OS & BLOCK_OS & GOV_OS & BETA & LEV & SIZE & ROA & ROE & TOBINQ & SALES_G \\
\hline Mean & 0.589 & 0.636 & 0.099 & 0.753 & 0.162 & 5787028 & 6.035 & 8.751 & 815.012 & 5.365 & \\
Median & 0.643 & 0.681 & 0.000 & 0.634 & 0.117 & 668183 & 4.820 & 8.605 & 84.995 & 0.460 \\
Maximum & 1.089 & 1.000 & 0.885 & 2.219 & 0.738 & 339621489 & 50.290 & 68.470 & 19361.140 & 1409.040 \\
Minimum & 0.000 & 0.015 & 0.000 & 0.008 & 0.000 & 2992 & -23.280 & -98.390 & 0.109 & -174.280 \\
Std. Dev. & 0.252 & 0.221 & 0.198 & 0.501 & 0.172 & 15285952 & 7.338 & 15.085 & 2464.567 & 97.639 \\
Skewness & -0.632 & -0.639 & 2.198 & 0.801 & 1.128 & 5.216 & 1.323 & -1.591 & 5.433 & 12.123 \\
Kurtosis & 2.524 & 2.750 & 6.981 & 2.902 & 3.668 & 35.323 & 9.765 & 15.232 & 35.964 & 172.178 \\
Jarque-Bera & 19.135 & 17.817 & 369.268 & 27.026 & 58.104 & $12,112.540$ & 554.081 & $1,677.369$ & $12,649.230$ & $306,694.600$ \\
Probability & 0.000 & 0.000 & 0.000 & 0.000 & 0.000 & 0.000 & 0.000 & 0.000 & 0.000 & 0.000 \\
Observations & 252 & 252 & 252 & 252 & 252 & 252 & 252 & 252 & 252 & 252
\end{tabular}

This table presents summary statistics for 252 MENA firms for the year 2014.

\section{Methodology and Model}

We used cross section data from nine countries to investigate the impact of ownership structure on firm's performance in the MENA region. We proxied performance by Tobin-Q, return on assets and return on equity. Our main explanatory variables are insider ownership, government agency, institutions, and blockholders. The model is presented below:

Tobin $\mathrm{Q}=\beta_{1}$ (In_OS $)+\beta_{2}$ (Block_OS $)+\beta_{3}$ (Gov_OS $)+\beta_{4}($ Lev $)+\beta_{5}($ Size $)+\beta_{6}($ Sales_G $)+\beta_{7}$ (Beta) $+\beta_{8}$ (Ind_Dum) $+\beta_{9}$ Country_Dum $+\varepsilon(1)$

ROA $=\beta_{1}($ In_OS $)+\beta_{2}($ Block_OS $)+\beta_{3}($ Gov_OS $)+\beta_{4}($ Lev $)+\beta_{5}($ Size $)+\beta_{6}($ Sales_G $)+\beta_{7}($ Beta $)+\beta_{8}($ Ind_Dum $)+$ $\beta_{9}$ Country_Dum $+\varepsilon(2)$

$\mathrm{ROE}=\beta_{1}\left(\mathrm{In} \_\mathrm{OS}\right)+\beta_{2}($ Block_OS $)+\beta_{3}($ Gov_OS $)+\beta_{4}(\mathrm{Lev})+\beta_{5}($ Size $)+\beta_{6}($ Sales_G $)+\beta_{7}($ Beta $)+\beta_{8}($ Ind_Dum $)+$ $\beta_{9}$ Country_Dum $+\varepsilon(3)$

We started by testing for heteroscedasticity using White test. We found evidence of heteroscedasticity and usedcorrected heteroscedasticity consistent standard errors. We controlled for government fixed effect by embodying country fixed effect dummy variables (Country_Dum). In addition we controlled for size, growth, industry type, firm's leverage and risk by including the log of total assets(Size), growth rate of sales (Sales_G), using industry type (Ind_Dum), total debt divided by total assets(lev) and Firm's beta (Beta), respectively. 


\section{Empirical Results}

We started by employing the White heteroscedasticity test and found evidence of heteroscedasticity, so corrected for heteroscedasticity using White consistent standard errors. We ran three different regressions, each using one definition of the firm performance as the dependent variable against our main ownership variables and the control variables. We estimated the effect of ownership characteristics represented by insider ownership, block ownership, and government ownership on firm performance. We used three proxies for firm's performance: Tobin-Q, returns on assets (ROA), and return on equity (ROE).

We found a positive impact of blockholders ownership on firm's Tobin-Q. Our results are consistent with the results of Aggarwal et al. (2011),Elyasiani and Jia (2010) and Barzegar and Babu (2008). Blockholders have more interest in monitoring firms operation more effectively than individual investors, and they have the ability to absorb and process information, which decreases the information asymmetry. In addition, blockholders have huge voting rights, and as a result, they become involved with the operating decisions of the firm. Thus, blockholders ownership acts as a mechanism to overcome free riding problems and decreases the difficulty in monitoring managers. Other ownership variables did not significant affect firm Tobin-Q.

We found a significant negative relation between firm's ROE and insider ownership. This finding is consistent with Krivogorsky(2006). This negative relation can be attributed to a situation where insider ownership can encourage risk taking, which could damage the firm's profitability instead of improving it.We didn't find significant impact of blockholders or government ownership on firm's ROE.

Finally, we found a positive significant impact of government ownership on firm's ROA. Our result is consistent with Borisova et al. (2012), and Jiang et al. (2008). Governmental ownership entitled it to enact regulations to ease the access to information which reduced the information asymmetry. In addition, government ownership may results in government support and protection to the industry which can have a positive impact on profitability.

All regressions include the following control variables: the log of total assets, growth rate of sales, industry type, leverage, and firm's beta. The size of the firm does not seem to have a significant effect on ROA and ROE, but it has a positive impact on Tobin-Q. The results show that statistically there is a significant negative relationship between the leverage and firm's ROE and ROA. This could indicate that companies with high debt due to borrowing incur costs which reduce net income and in return will reduce ROA and ROE. Our results show that risk negatively affects ROA but has an insignificant impact on ROE. Moreover, we find that firm's beta positive affect firm's Tobin-Q and this results is consistent with Villalonga et al. (2006). Finally, we find that sales growth positively affect ROA and ROE. This may indicate that higher revenue generated from sales improves the position of the firm. 
Table 2. The impact of ownership structure on firm's Tobin-Q

\begin{tabular}{ll}
\hline Independent variable & \\
\hline INSID_OS & -0.884 \\
BLOCK_OS & $1.813^{* *}$ \\
GOV_OS & 0.294 \\
BETA & $1.335^{* * *}$ \\
LEV & $0.801 *$ \\
SIZE & $0.000^{* * *}$ \\
IND1 & $0.331^{*}$ \\
IND2 & $1.529 * * *$ \\
IND3 & 0.109 \\
IND4 & 0.050 \\
SALES_G & $-0.001 * * *$ \\
DUM1 & $4.101 * * *$ \\
DUM2 & $3.116^{* * *}$ \\
DUM3 & $3.512 * * *$ \\
DUM4 & $1.306 * * *$ \\
DUM5 & -0.712 \\
DUM6 & $3.011 * * *$ \\
DUM7 & $2.941 * * *$ \\
DUM8 & $2.075 * * *$ \\
R-squared & 0.766 \\
Adjusted R-squared & 0.748 \\
Observations & 256 \\
\hline
\end{tabular}

Table 2. presents estimated regression results of:

Tobin $\mathrm{Q}=\beta 1($ In_OS $)+\beta 2($ Block_OS $)+\beta 3($ Gov_OS $)+\beta 4($ Lev $)+\beta 5($ Size $)+\beta 6($ Sales_G $)+\beta 7($ Beta $)+$ $\beta 8$ (Ind_Dum) $+\beta 9$ Country_Dum $+\varepsilon$

* Significance at $10 \%$

** Significance at $5 \%$

*** Significance at $1 \%$ 
Table 3. The impact of ownership structure on firm's ROA

\begin{tabular}{ll}
\hline Independent variable & \\
\hline INSID_OS & -1.621 \\
BLOCK_OS & 1.326 \\
GOV_OS & $5.370^{* *}$ \\
BETA & $-2.307 * *$ \\
LEV & $-10.261 * * *$ \\
SIZE & 0.000 \\
IND1 & $3.043 * *$ \\
IND2 & 0.308 \\
IND3 & 1.596 \\
IND4 & -1.767 \\
SALES_G & -0.003 \\
DUM1 & $6.308 * * *$ \\
DUM2 & $9.189 * * *$ \\
DUM3 & $7.740 * *$ \\
DUM4 & $5.099 * *$ \\
DUM5 & $7.084 * *$ \\
DUM6 & $12.41 * * *$ \\
DUM7 & $10.658 * * *$ \\
DUM8 & $9.965 * * *$ \\
R-squared & 0.187 \\
Adjusted R-squared & 0.124 \\
Observations & 253 \\
\hline
\end{tabular}

Table 3 presents estimated regression results of:

$\mathrm{ROA}=\beta 1\left(\mathrm{In} \_\mathrm{OS}\right)+\beta 2($ Block_OS $)+\beta 3($ Gov_OS $)+\beta 4($ Lev $)+\beta 5($ Size $)+\beta 6($ Sales_G $)+\beta 7($ Beta $)+$ $\beta 8$ (Ind_Dum) $+\beta 9$ Country_Dum $+\varepsilon$

* Significance at $10 \%$

** Significance at $5 \%$

*** Significance at $1 \%$ 
Table 4. The impact of ownership structure on firm's ROE

\begin{tabular}{ll}
\hline Independent variable & \\
\hline INSID_OS & $-15.947 *$ \\
BLOCK_OS & 8.782 \\
GOV_OS & 6.591 \\
BETA & $-3.578^{*}$ \\
LEV & $-24.635^{* * *}$ \\
SIZE & 0.000 \\
IND1 & 3.245 \\
IND2 & 3.482 \\
IND3 & 0.260 \\
IND4 & -0.490 \\
SALES_G & -0.004 \\
DUM1 & $13.130 * * *$ \\
DUM2 & $14.911 * * *$ \\
DUM3 & $19.859^{* * *}$ \\
DUM4 & $13.582 * *$ \\
DUM5 & $19.627 * * *$ \\
DUM6 & $24.086 * * *$ \\
DUM7 & $26.367 * * *$ \\
DUM8 & $21.564 * * *$ \\
R-squared & 0.158 \\
Adjusted R-squared & 0.093 \\
Observations & 253 \\
\hline
\end{tabular}

Table 2.3 presents estimated regression results of:

$\mathrm{ROE}=\beta 1($ In_OS $)+\beta 2($ Block_OS $)+\beta 3($ Gov_OS $)+\beta 4(\mathrm{Lev})+\beta 5($ Size $)+\beta 6($ Sales_G $)+\beta 7($ Beta $)+$ $\beta 8$ (Ind_Dum) $+\beta 9$ Country_Dum $+\varepsilon$

* Significance at $10 \%$

** Significance at $5 \%$

*** Significance at $1 \%$

\section{Conclusion}

This paper studies the effect of ownership structures on firm performance. We use three different proxies of firm's performance: Tobin-Q, return on equity(ROE) and return on assets(ROA). We rely on three variables to capture a firm's ownership structure: insider ownership, blockholder ownership and government ownership. The desire to study this topic springs from agap in literature covering the MENA region. No previous regional studies have focused on this topic, which provided an opportunity to question whether the ownership structures of firms in the MENA region had similar effects such as that suggested by empirical research on other regions.

We used panel data for nine MENA countries: Egypt, Bahrain, Qatar, Kuwait, Tunisia, Dubai, UAE, Morocco, Oman and Jordan. We ran three different regressions for each of our dependent variables: Tobin-Q, ROA, and ROE. Our results suggest that insider ownership negatively affects a firm's return on equity. We also found that blockholder ownership has a positive impact on a firm's Tobin-Q. Finally, we found that governmental ownership has a positive impact on firm's return on assets. This result is consistent with the positive impact of blockholders on ROE, since in these countries government ownership is considerably large. 


\section{References}

Anderson, R. C., \& Reeb, D. (2003). Founding-Family Ownership and Firm Performance: Evidence from the S\&P 500. The Journal of Finance, 58(3), 1301-1327. https://doi.org/10.1111/1540-6261.00567

Andres, C. (2008). Large shareholders and firm performance-An empirical examination of founding-family ownership. Journal of Corporate Finance, 14(4), 431-445. https://doi.org/10.1016/j.jcorpfin.2008.05.003

Arosa, B., Iturralde, T., \& Maseda, A. (2009). Ownership Structure, Insiders Ownership and Firm Performance in Spanish Non-Listed Firms. https://doi.org/10.2139/ssrn.1505308

Berle, A. A., \& Means, G. C. (1932). The Modern Corporation and Private Property. Transaction Publishers.

Blair, M. M. (1995). Ownership and control: rethinking corporate governance for the twenty-first century. Challenge, 39(1). Retrieved from http://www.jstor.org/stable/40721671

Brigham, E. F., \&Daves, P. R. (n.d.). Intermediate Financial Management (9th ed.).

Cho, D.-S., \& Kim, J. (2007). Outside Directors, Ownership Structure and Firm Profitability in Korea. Corporate Governance: An International Review, 15(2), 239-250. https://doi.org/10.1111/j.1467-8683.2007.00557.x

CIMA: Fundmentals of ethics, corporate governance and business law. (2010). BPP Learning Media Ltd.

Core, J. E., Holthausen, R. W., \& Larcker, D. F. (1999). Corporate Governance, Chief Executive Officer Compensation and Firm Performance. Journal of Financial Economics, 371-406. https://doi.org/10.1016/S0304-405X(98)00058-0

DeAngelo, L., \& DeAngelo, H. (2000). Controlling Stockholders and the Disciplinary Role of Corporate Payout Policy: A Study of the Times Mirror Company. Journal of Financial Economics, 153-207. https://doi.org/10.1016/S0304-405X(00)00039-8

Demsetz , H. (1983). The Structure of Ownership and the Theory of the Firm. Journal of Law and Economics, 26(2), 375-390. https://doi.org/10.1086/467041

Eelderink, G. (2014). Effect of ownership structure on firm performance. Retrieved from http://purl.utwente.nl/essays/65629

Financial Reporting Council. (2014). The UK Corporate Governance Code. London.

Gorton, G., \& Schmid, F. A. (1996). Universal Banking and the Performance of German Firms. Journal of Financial Economics. https://doi.org/10.3386/w5453

Harris, M., \&Raviv, A. (1991). The Theory of Capital Structure. The Journal of Finance, 46(1), $297-355$. https://doi.org/10.1111/j.1540-6261.1991.tb03753.x

Hill, C. W., \& Snell, S. A. (2006). External control, corporate strategy, and firm performance in research-intensive industries. Strategic Management Journal, 9(6), 577-590. https://doi.org/10.1002/smj.4250090605

Himmelberg, C. P., Hubbard , R., \& Palia, D. (1999). Understanding the determinants of managerial ownership and the link between ownership and performance. Journal of Financial Economics, 53(3), 353-384. https://doi.org/10.1016/S0304-405X(99)00025-2

Hitt, M. A., Ireland, R. D., \& Hoskisson, R. E. (2006). Strategic Management Concepts and Cases: Competitivness and Globalization. South-Western College.

Hitt, M., Duane, R., \&Hoskisson, R. (2006). Strategic Management: Concepts and Cases. Cengage Learning.

Ismail, A. (2009). Private Eqyity and Venture Capital in Emerging Markets: A Case Study of Egypt and the MENA region.

James, C., \& Brickley, J. (1987). The takeover market, corporate board composition, and ownership structure: The case of banking. Journal of Law and Economics.

Jensen, M. C., \& Meckling, W. H. (1976). Theory of the Firm: Managerial Behavior, Agency Costs and Ownership Structure. Journal of Financial Economics, 3(4). https://doi.org/10.1016/0304-405X(76)90026-X

Krivogorsky, V. (2006). Ownership, board structure, and performance in continental Europe. International Journal of Accounting, 41(2), 176. https://doi.org/10.1016/j.intacc.2006.04.002

Lehn, K., \& Demsetz, H. (1985). The Structure of Corporate Ownership: Causes and Consequences. Journal of Political Economy, 93(6), 1155-77. https://doi.org/10.1086/261354 
Loderer, C. M. (1997). Executive stock ownership and performance tracking faint traces. Journal of Financial Economics, 45, 223-255. https://doi.org/10.1016/S0304-405X(97)00017-2

Madura, J., \& Gitman, L. J. (2000). Introduction to Finance. Addison Wesley.

Marcus, A. J., Bodie, Z., \& Kane, A. (2009). Investments (eighth ed.). McGraw-Hil.

Mayer, C. (1988). New issues in corporate finance. European Economic Review, 1167-1183. https://doi.org/10.1016/0014-2921(88)90077-3

McConnell, J. J., \& Servaes, H. (1990). Additional evidence on equity ownership and corporate value. Journal of Financial Economics, 27(2), 595-612. https://doi.org/10.1016/0304-405X(90)90069-C

Morck, R., Shleifer, A., \& Vishny, R. W. (1988). Management ownership and market valuation: An empirical analysis. Journal of Financial Economics, 20(1), 293-315. https://doi.org/10.1016/0304-405X(88)90048-7

Morck, Randal, Nakamura, M., \& Shivdasani, A. (2000). Banks, ownership structure, and firm value in Japan. Journal of Business, 73(4), 539-567. https://doi.org/10.1086/209654

Mudambi , R., \& Nicosia , C. (1998). Ownership Structure and Firm Performance: Evidence from the UK Financial Services Industry. Applied Financial Economics, 8, 175-180. https://doi.org/10.1080/096031098333159

Myers, S. C., \& Majluf, N. S. (1984). Corporate Financing and Investment Decisions When Firms Have Information That Investors Do Not Have. Journal of Financial Economics, 13(2), 187-221. https://doi.org/10.1016/0304-405X(84)90023-0

Ngui , K. S., Voon , M. L., \& Lim , E. A. (2008). The Effects of Insider and Blockholder Ownerships on Firm Performance: The Mediating Role of Internal Governance Mechanisms. https://doi.org/10.2139/ssrn.1095138

Prowse, S. (1992). The Structure of Corporate Ownership in Japan. The Journal of Finance. https://doi.org/10.1111/j.1540-6261.1992.tb04007.x

(ROSC) Reports on the Observance of Standards \& Codes. (2009). Retrieved from http://www.worldbank.org/ifa/rosc_cg_egy.pdf.

Shivdasani, A., \& Yermack, D. (n.d.). CEO involvement in the selection of new board members: An empirical analysis. Journal of Finance, 54, 1829-1853.

Shleifer, A., \& Vishny, R. (1997). A Survey of Corporate Governance. The Journal of Finance. https://doi.org/10.1111/j.1540-6261.1997.tb04820.x

Thomsen, S., \&Conyon, M. (2012). Corporate Governance: Mechanisms and Systems. McGraw-Hill Higher Education.

Tribo, J., Berrone, P., \& Jordi Surroca, J. (2007). Do the Type and Number of Blockholders Influence R\&D Investments? New evidence from Spain. Corporate Governance, 15(5). https://doi.org/10.1111/j.1467-8683.2007.00622.x

Villalonga , B., \& Amit, R. H. (2006). How Do Family Ownership, Control and Management Affect Firm Value? Journal of Financial Economics, 80(2), 385-417. https://doi.org/10.1016/j.jfineco.2004.12.005

Wiwattanakantang, Y. (1999). An Empirical Study on the Determinants of the Capital Structure of Thai Firms. Pacific Basin Finance Journal, 7. https://doi.org/10.1016/S0927-538X(99)00007-4

Wiwattanakantang, Y. (2000). Controlling shareholders and corporate value. Pacific-Basin Finance Journal, 9, 323-362. https://doi.org/10.1016/S0927-538X(01)00022-1

Wright, J., Gonenc, H., \& Seifert, B. (2005). The International Evidence on Performance and Equity Ownership by Insiders, Blockholders, and Institutions. Journal of multinational financial management, 15(2), 171-191. https://doi.org/10.1016/j.mulfin.2004.08.003

Yammeesri, J. (2003). Corporate governance: ownership structure and firm performance - evidence from Thailand. Retrieved from http://ro.uow.edu.au/theses/1908. 